\title{
Correlations between iron content in knee joint tissues and chosen indices of peripheral blood morphology
}

\author{
Barbara Brodziak-Dopierała ${ }^{1, A, ~,-E}$, Wojciech Roczniak 2, B, E, F, Agata Jakóbik-Kolon 3, B, Joanna Kluczka, B, \\ Bogdan Koczy ${ }^{4, B}$, Jerzy Kwapuliński ${ }^{5}$,, Magdalena Babuśka-Roczniak ${ }^{2, B, E}$ \\ ${ }^{1}$ Department of Toxicology, Medical University of Silesia, Katowice, Poland \\ 2 Jan Grodek State Vocational Academy, Sanok, Poland \\ ${ }^{3}$ Silesian University of Technology, Gliwice, Poland \\ ${ }^{4}$ The Dr Janusz Daab District Hospital of Orthopedics and Trauma Surgery, Piekary Śląskie, Poland \\ ${ }^{5}$ Institute of Occupational Medicine and Environmental Health, Sosnowiec, Poland \\ A - research concept and design; $B$ - collection and/or assembly of data; $C$ - data analysis and interpretation; \\ $D$ - writing the article; $E$ - critical revision of the article; $F$ - final approval of article
}

Address for correspondence

Barbara Brodziak-Dopierała

E-mail: bbrodziak@sum.edu.pl

Funding sources

None declared

Conflict of interest

None declared

Received on September 28, 2015

Revised on June 6, 2016

Accepted on August 24, 2016

\begin{abstract}
Background. Iron as a cofactor of enzymes takes part in the synthesis of the bone matrix. Severe deficiency of iron reduces the strength and mineral density of bones, whereas its excess may increase oxidative stress. In this context, it is essential to determine the iron content in knee joint tissues.

Objectives. The study objective was to determine the level of iron in the tissues of the knee joint, i.e., in the femoral bone, tibia and meniscus.
\end{abstract}

Material and methods. Material for analysis was obtained during endoprosthetic surgery of the knee joint. Within the knee joint, the tibia, femur and meniscus were analyzed. Samples were collected from 50 patients, including 36 women and 14 men. The determination of iron content was performed with the ICPAES method, using Varian 710-ES.

Results. The lowest iron content was in the tibia $(27.04 \mu \mathrm{g} / \mathrm{g})$, then in the meniscus $(38.68 \mu \mathrm{g} / \mathrm{g})$ and the highest in the femur $(41.93 \mu \mathrm{g} / \mathrm{g})$. Statistically significant differences were noted in the content of iron in knee joint tissues.

Conclusions. In patients who underwent endoprosthesoplasty of the knee joint, statistically significant differences were found in the levels of iron in various components of the knee joint. The highest iron content was found in the femoral bone of the knee joint and then in the meniscus, the lowest in the tibia. The differences in iron content in the knee joint between women and men were not statistically significant.

Key words: iron, bone tissue, tibia, femur

DOI

10.17219/acem/64823

\section{Copyright}

Copyright by Author(s)

This is an article distributed under the terms of the

Creative Commons Attribution Non-Commercial License

(http://creativecommons.org/licenses/by-nc-nd/4.0/) 
Iron is a cofactor in many enzymes and cell redox reactions. A low level of iron ions may be harmful for the cell, whereas an excessive amount may cause the generation of reactive oxygen species via Fenton's reaction. Cellular iron content is strictly regulated by homeostatic mechanisms to maintain its adequate level in the cell. The ions of nickel and other divalent metals can compete with iron ions to enter the cell through divalent metal transporter 1 (DMT1), as they have similar ion rays. Therefore, metal ions can affect many other cell iron-dependent processes. ${ }^{1}$

Iron as an enzymatic cofactor takes part in the synthesis of the bone matrix (lysyl hydroxylase activation) and 25-hydroxycholecalciferol hydrolase. ${ }^{2}$ Moreover, Fe ions aided by active vitamin $\mathrm{D}$ stimulate the absorption of $\mathrm{Ca}$ ions in the intestine. Iron deficiencies in rats led to poor mineralization of their skeletons and pathological lesions in the microarchitecture of the spongy matter of the vertebrae. ${ }^{3,4}$ In turn, estrogen administration increased the accumulation of iron in hamsters and facilitated its intake by lymphocytes in culture. ${ }^{1,5}$

Deficiency of Fe ions in young rats led to a decrease in mechanical strength of the femoral bone and cortical bone. ${ }^{6}$ In severe deficiency, strength and mineral density of the bone was reduced.

An excess of iron content in mice led to increased oxidative stress, which mediates bone mass loss through bone rebuilding. ${ }^{8}$

In rats with severe anemia due to iron deficiency, the concentration of procollagen type I N-terminal pro-peptide was low, which caused a decrease in bone matrix formation and mineralization. ${ }^{9}$ These parameters returned to normal following the intake of dietary iron. ${ }^{10}$ No data is available on the significance of iron for the health of bones in humans. On the other hand, osteopenia was observed in patients with genetically conditioned hemochromatosis and a very high iron content in tissues. ${ }^{11}$ Thus, the protective or destructive effects of iron on bones depend on its concentration. ${ }^{2}$

Anemia due to iron deficiency has a great impact for health. Deficiency of iron ions in women at reproductive age and in adolescents may also affect bone health at the time when peak bone mass is acquired. ${ }^{12}$

Results reported by Harris et al. indicate that an increase in the level of iron can be essential to prevent fractures, especially in some groups, such as elderly women, former female athletes and female army workers. ${ }^{13}$

As shown by a recent study, patients with osteoporosis have iron deficiency, i.e., a lower concentration of iron ions and higher serum transferrin level, as compared to a control group. ${ }^{14}$

Additionally, rats with general iron deficiency have lower bone mass than animals with high iron level. However, no such correlation has been noted in people.

An increasing number of studies suggest the existence of correlations between lipid oxidation and bone metabolism, as well as between iron metabolism and LDL oxidation. The availability of iron ions for cells also depends on the haptoglobin phenotype. ${ }^{15}$ It has been found that in postmenopausal women, Hp 1.1 and 2.2 are associated with greater risk of fractures as compared to Hp 2.1. The relationship between $\mathrm{Hp}$ and bone mass results from its role in iron metabolism and antioxidant properties, since serum iron levels in patients suffering from osteoporosis are lower than in healthy control subjects. The patients had greater amounts of oxLDL (oxidized low-density lipoproteins) as compared to the controls. ${ }^{15}$

Zheng et al. revealed that low serum levels of iron were associated with osteoporosis. ${ }^{8}$ Previous studies have reported that patients with osteoporosis suffer from iron deficiency, which in turn may decrease iron bioavailability and affect bone metabolism. In that case, iron acts as a cofactor in the enzymes involved in the synthesis of intracellular substances of the bone, and in the vitamin D enzyme and hydroxylase, engaged in vitamin D activation. Animal studies indicate that Fe deficiency is accompanied by a reduced level of osteocalcin, the mineral content of bones, lowered density of bone tissue and mechanical strength of the femur. Iron loss in the culture of osteoblasts induced mineralization disorders, similar to those observed in some human populations. Mineralization disorders induced by iron deficiency seem to be a possible mechanism in osteoporosis. ${ }^{8}$

The above literature survey shows a major role of iron content in the human body. However, no information is available on the role of iron ions in the tissues of the knee joints in relation to chosen morphological indices as the main pathway of general iron distribution.

\section{Material and methods}

The study material included parts of the knee joint obtained during endoprosthesoplasty in the Dr Janusz Daab District Hospital of Orthopedics and Trauma Surgery in Piekary Śląskie, Poland. Biological samples were obtained from patients living in Silesia Province. Samples were collected from 50 patients, 36 women and 14 men. In 26 patients the right leg and in 24 patients the left leg was involved. The mean age of the whole study population was 67.5 years, being slightly lower in women (67.2 years), than in men (68.1 years).

Degenerative disease of the knee joint and considerable pain were indications for this type of procedure. In the study group, the patients complained of pain of 10 years' duration on average. The study was approved by the Bioethics Committee, no. 2/2013 of June 18 ${ }^{\text {th }}, 2013$.

Surgeries were performed under subarachnoid anesthesia, with patients in the prone position. Esmarch bandage was used for exsanguination of the limb. The frontal surface of the knee joint was exposed, following the standard preparation of the operation field (applying antiseptic and aseptic techniques) with straight midline incision. The joint was opened at the medial side and the hypertro- 
phic synovium was removed. Using ZIMMER instrumentation, the femoral part of the knee joint was prepared by processing the distal femur and performing femoral epicondyle osteotomy. Next, damaged menisci were removed and the tibial part was prepared using ZIMMER instrumentation (resection of the tibial plateau). In this way, the osseous components, cartilages and parts of menisci were used for measurements.

The material samples were described and stored in modified polyethylene containers, in a freezer at a temperature of $-22^{\circ} \mathrm{C}$.

Tissue samples with a known mass were mineralized using $4 \mathrm{~cm}^{3}$ of spectrally pure $\mathrm{HNO}_{3}(\mathrm{~V})$ (Supra pure, Merck, Dormstadt, Germany), in a Magnum II (ERTEC) microwave mineralizer. The samples were placed one by one in a Teflon vessel and submitted mineralization. Mineralization was a 2 -stage procedure. The $1^{\text {st }}$ stage lasted 2 min at 20 bar max pressure and $255^{\circ} \mathrm{C}$ max. temperature, whereas the $2^{\text {nd }}$ stage was of 6 min duration at 45 bar max pressure and $285^{\circ} \mathrm{C}$ max. temperature. The post-mineralization solution was transferred to a $25 \mathrm{~cm}^{3}$ flask and then diluted to the $\mathrm{mL}$ mark with redistilled water.

The content of iron in the mineralized samples was determined using inductively coupled plasma atomic emission spectrometry (ICP-AES). A Varian 710-ES spectrometer equipped with a OneNeb nebulizer was utilized. The following parameters were used: RF power $1.0 \mathrm{~kW}$, plasma flow $15 \mathrm{~L} / \mathrm{min}$, auxiliary flow $1.5 \mathrm{~L} / \mathrm{min}$, nebulizer pressure $210 \mathrm{kPa}$, pump rate $15 \mathrm{rpm}$, emission lines of Fe: $\lambda=238.204$ and $259.940 \mathrm{~nm}$. The calibration curve method was applied. The standard solutions of $1 \mathrm{mg} / \mathrm{mL}$ (Millipore SAS, Molsheim, France) as well as deionized water (Elix Essential 10) were used. The results are an average of the concentrations obtained for all analytical lines used for the element, with standard deviation not exceeding $1.5 \%$. The accuracy of the analysis was controlled using Standard Reference Material 1400 Bone Ash (NIST).

Hematological indices were marked on the BC-5380 hematology analyzer, number RF-21101836, year of production: 2012. The analyzer is under constant supervision of an authorized service, and undergoes annual inspection and service-maintenance procedures. Quality control is conducted internally (daily at 3 levels: low, normal and high, 365 days a year) and externally (24 times a year) (RIQAS).

The study objective was to determine the level of iron in the tissues of the knee joint, i.e., in the femoral bone, tibia and meniscus. Statistical analysis of the results was performed separately for women and men, with a division into the right and left limb. Correlation analysis was used to assess the role of iron content in relation to chosen morphological parameters of the peripheral blood measured on the day of admission to hospital. The aim of the research was also to determine factors that may affect the content of iron in tissues of the knee joint, i.e., smoking and previously implanted prostheses.

\section{Statistical analysis}

The analysis used STATISTICA PL v. 10.0 (StatSoft, Inc., Tulsa, USA) software.

To determine the distribution of the results, the Shapiro-Wilk's test was used $(\mathrm{p}<0.05)$. The distribution of results was an abnormal distribution.

The results of the study were presented in arithmetic mean values. The tables that describe the content of iron in the tissues of the knee contained: arithmetic mean, standard deviation, median, and range of changes. Hematological indices were presented by the arithmetic mean, standard deviation, median, range of changes, and the coefficient of variation.

The analysis of differences in iron concentration between different treatment groups was made using the Mann-Whitney U-test.

To evaluate differences in the content of iron in various tissues of the knee joint, the Kruskal-Wallis ANOVA rank test was used. The same test was used in analyzing the differences in the iron content in the population of smokers and non-smokers, and in different age groups.

Additionally, Spearman's rank correlation between iron and the hematological indices in the population of women and men was determined. Significant rho correlation coefficients occurred at a probability level of $\mathrm{p}<0.05$.

\section{Results}

The results related to iron content in the chosen tissues of the knee joint have been presented in Fig. 1. The lowest iron content was in the tibia $(27.04 \mu \mathrm{g} / \mathrm{g})$, then in the meniscus $(38.68 \mu \mathrm{g} / \mathrm{g})$, and the highest in the femur $(41.93 \mu \mathrm{g} / \mathrm{g})$ (Table 1). Statistically significant differences were noted in the content of iron in knee joint tissues (ANOVA Kruskal-Wallis rank test, $\mathrm{p}=0.052$ ).

No statistically significant differences were noted in iron content in the tibia between women and men. The Fe levels were higher in women than in men. In the femoral bone, the levels of iron were also higher in women than in men. In the meniscus, higher iron content was found in men than in women, although the differences were not statistically significant (Table 2).

In both women and men, no statistically significant differences were observed between the tissues of the left and right limb (Table 3).

Table 1. Iron content in knee joint tissues $(\mu \mathrm{g} / \mathrm{g})$

\begin{tabular}{|l|c|c|c|}
\multicolumn{1}{c|}{} & AM \pm SD & Med & Range \\
\hline Tibia $n=50$ & $27.04 \pm 22.04$ & 20.07 & $2.32-99.27$ \\
\hline Femur $n=50$ & $41.93 \pm 67.44$ & 17.20 & $3.69-410.01$ \\
\hline Meniscus $n=50$ & $38.68 \pm 29.66$ & 29.61 & $5.90-118.82$ \\
\hline
\end{tabular}

AM - arithmetic mean; SD - standard deviation; Med - median. 
Fig. 1. Iron content in knee joint tissues in female and male smokers and nonsmokers
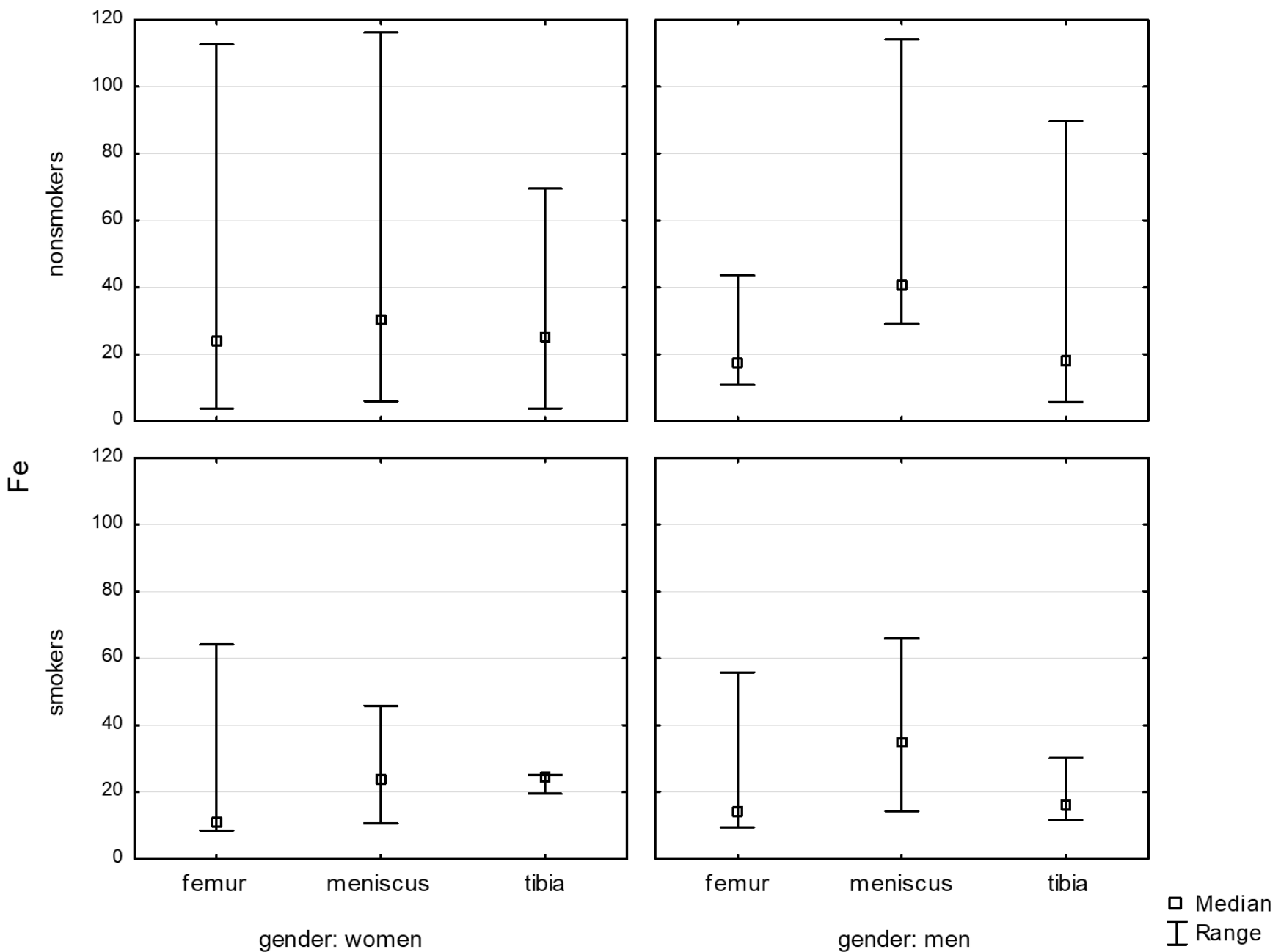

The comparison of the averages for both genders combined showed that the $\mathrm{Fe}$ content was higher in nonsmokers $(39.11 \mu \mathrm{g} / \mathrm{g})$ as compared to smokers $(25.47 \mu \mathrm{g} / \mathrm{g})$. In the group of female smokers, the content was close to that observed in male smokers $(24.43 \mu \mathrm{g} / \mathrm{g}$ vs $26.50 \mu \mathrm{g} / \mathrm{g})$. However, in the group of non-smoking women, the level was $39.68 \mu \mathrm{g} / \mathrm{g}$ vs $36.40 \mu \mathrm{g} / \mathrm{g}$ in men (Fig. 1).

In patients who had already undergone endoprosthesoplasty of the other knee, the content of Fe was $32.81 \mu \mathrm{g} / \mathrm{g}$,

which was lower than in patients who had never had that type of surgery $(36.96 \mu \mathrm{g} / \mathrm{g})$. However, the differences were not statistically significant.

There were statistically significant differences in the content of iron in the tissues of the knee joint according to age (Kruskal-Wallis ANOVA Rank Test, $\mathrm{p}=0.055$ ).

The chosen morphological parameters have been presented in Table 4. In women, the values of all hematological indices were lower as compared to men.

Table 2. Iron content in knee joint tissues in women and men $(\mu \mathrm{g} / \mathrm{g})$

\begin{tabular}{|c|c|c|c|c|}
\hline & & Tibia $n=36$ & Femur $n=36$ & Meniscus $\mathrm{n}=36$ \\
\hline \multirow{3}{*}{ Women } & $\mathrm{AM} \pm \mathrm{SD}$ & $29.05 \pm 22.30$ & $43.42 \pm 73.80$ & $36.61 \pm 27.54$ \\
\hline & med & 23.13 & 17.45 & 28.5 \\
\hline & range & $2.32-99.27$ & $3.69-410.01$ & $5.90-116.34$ \\
\hline \multirow{3}{*}{ Men } & $\mathrm{AM} \pm \mathrm{SD}$ & $21.88 \pm 21.26$ & $38.08 \pm 49.57$ & $44.00 \pm 35.08$ \\
\hline & med & 16.3 & 16.45 & 37.45 \\
\hline & range & $5.71-89.62$ & $9.45-197.22$ & $7.48-118.82$ \\
\hline Women vs men & $M-W$ test & ns & ns & ns \\
\hline
\end{tabular}

AM - arithmetic mean; SD - standard deviation; med - median; M-W test - Mann-Whitney U test; ns - non-significant difference. 
Fig. 2. Spearman's correlation analysis between iron content in knee joint tissues and hematological indices in women and men

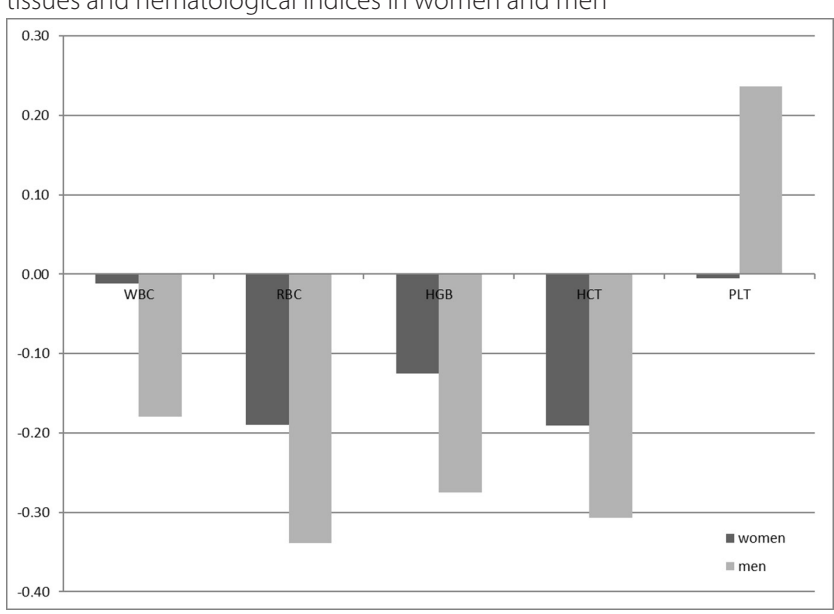

The correlation analysis showed a relationship of the level of $\mathrm{Fe}$ in the knee joint with $\mathrm{RBC}$ in women (rho = -0.19) and men (rho = -0.34) and with HCT in women (rho $=-0.19)$ and men (rho $=-0.31)$ (Fig. 2).

\section{Discussion}

Articular degeneration is a chronic, non-inflammatory disease of multifactorial etiology. As a result of chronic joint destruction, the patient suffers from locomotor dysfunction and complains of impaired performance and difficulty in everyday functioning. As a consequence, the quality of life is reduced. ${ }^{16}$

Bone tissue, due to long restoration and retention time, is considered a biomarker of exposure to trace elements. ${ }^{17-20}$ Bones are characterized by a very slow exchange of elements, whose biological half-lives are estimated to be a few years to several decades. The content of elements in bone tissue and of some trace elements have been frequently assessed in numerous studies. ${ }^{18-23}$

The comparison of gender-related iron concentrations showed that the lower level of the element in the knee joint of women as compared to men was in the meniscus. The iron content in the femur and tibia was found to be higher than in men. In the knee joint tissues, a lower iron concentration in women was observed only in the articular cartilage, whereas it was higher in all other components of the joint in women. The reasons for the statistically significant differences in the iron content in the tissues of the knee joint are the diverse metal accumulation capacities of each type of tissues, the location of these tissues and environmental exposure.

Iron concentrations in both populations were very similar. No statistically significant differences were found in the femur, tibia and meniscus between patients without knee endoprosthesis and those with implanted endoprosthesis. A comparison of the respective tissues in the knee joint showed a higher content of iron in the meniscus in patients with knee endoprosthesis $(44.50 \mu \mathrm{g} / \mathrm{g})$ than in those without one $(36.63 \mu \mathrm{g} / \mathrm{g})$. In the femur and tibia, the level of iron was higher in subjects without endoprosthesis (33.15 and $27.59 \mu \mathrm{g} / \mathrm{g} ; 28.44$ and $25.49 \mu \mathrm{g} / \mathrm{g}$, respectively).

In nonsmokers, the levels of iron in the femur, tibia and meniscus differed statistically significantly (ANOVA Kruskal-Wallis rank test, $\mathrm{p}=0.088$ ). The differences were not observed in smokers.

The reason for differences in the content of iron in the tested tissues is likely to result from ongoing degenerative changes in the knee joint. Consequently, there are abnormalities in the blood supply of tissues, which may have an impact on the content of elements in these tissues.

It turned out that the content of iron determined in the knee joint of patients living in Silesia Province was

Table 3. Iron content in the right and left knee joint in women and men $(\mu \mathrm{g} / \mathrm{g})$

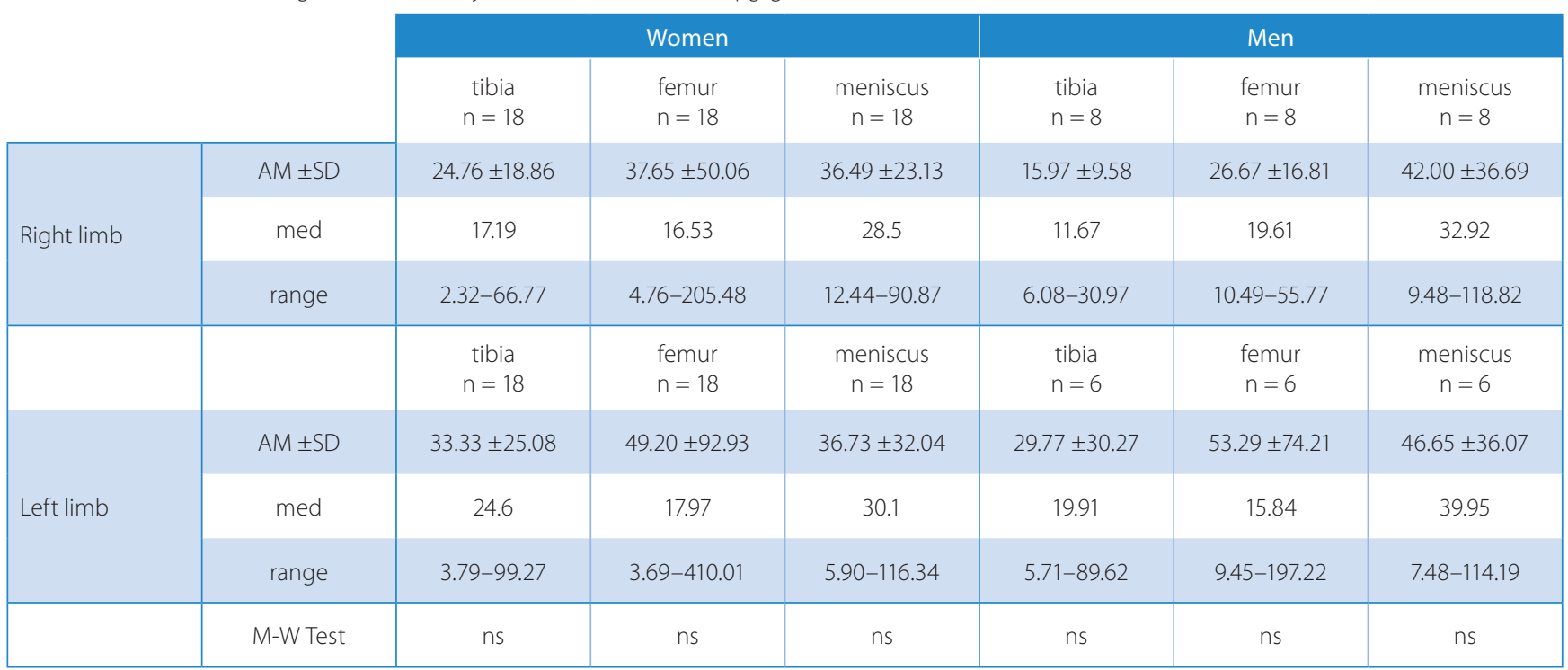

AM - arithmetic mean; SD - standard deviation; med - median; M-W test - Mann-Whitney U test; ns - non-significant difference. 
Table 4. Chosen morphological parameters of the peripheral blood in women and men undergoing endoprosthesoplasty of the knee joint

\begin{tabular}{|c|c|c|c|c|c|}
\hline & & $\mathrm{AM} \pm \mathrm{SD}$ & Med & Range & CV \\
\hline \multirow{5}{*}{ Women } & WBC & $6.87 \pm 1.61$ & 6.64 & $4.14-10.83$ & 23 \\
\hline & $\mathrm{RBC}$ & $4.54 \pm 0.47$ & 4.61 & $3.30-5.34$ & 10 \\
\hline & $H G B$ & $13.37 \pm 2.02$ & 13.80 & $4.54-15.70$ & 15 \\
\hline & PLT & $238.89 \pm 63.36$ & 235.00 & $103.00-341.00$ & 27 \\
\hline & $\mathrm{HCT}$ & $41.04 \pm 3.83$ & 41.75 & $32.50-47.90$ & 9 \\
\hline \multirow{5}{*}{ Men } & WBC & $7.51 \pm 2.35$ & 7.42 & $4.45-13.40$ & 31 \\
\hline & $\mathrm{RBC}$ & $4.79 \pm 0.37$ & 4.94 & $4.22-5.24$ & 8 \\
\hline & $H G B$ & $14.52 \pm 1.02$ & 14.50 & $12.40-16.20$ & 7 \\
\hline & PLT & $254.21 \pm 72.63$ & 263.00 & $155.00-400.00$ & 29 \\
\hline & HCT & $43.31 \pm 3.05$ & 43.75 & $36.30-47.90$ & 7 \\
\hline
\end{tabular}

AM - arithmetic mean; SD - standard deviation; Med - median; CV - coefficient of variation.

higher as compared to the results reported by Kuo et al., relating to the bones of inhabitants of Taiwan $-20.3 \mu \mathrm{g} / \mathrm{g} .{ }^{24}$

For comparison, the iron content in the bones determined by Bush et al. was $54 \mu \mathrm{g} / \mathrm{g}$ on average, slightly higher than in our study. ${ }^{25}$

In other bone tissues, e.g., the ribs, iron content was $140 \mathrm{mg} / \mathrm{kg}$, a few times higher than in our study. ${ }^{26}$ Subsequent findings reported by Scancar et al. confirm the correlation between iron content and the type of bone tissue, e.g., in the iliac crest it was $100-300 \mathrm{mg} / \mathrm{kg}$ and, as shown by Takata et al., in the cancellous bone of the ribs it was $377 \mu \mathrm{g} / \mathrm{g} .{ }^{27-28}$

Iron concentration in the knee joint is a few times lower than in the hip joint. The discrepancy is due to the application of different methods: ICP-AES in the knee joint and AAS in the hip joint. Moreover, in the latter case, iron level was determined in the head of the femur with division into articular cartilage, cortical bone and spongy bone. In the knee joint, measurements were done in the femur and tibia, with no division into tissues. For instance, in the articular cartilage of the femoral bone, iron concentration was $183.75 \mu \mathrm{g} / \mathrm{g}$, in the cortical bone $111.16 \mu \mathrm{g} / \mathrm{g}$, and in the spongy bone $163.25 \mu \mathrm{g} / \mathrm{g} .{ }^{29} \mathrm{How}-$ ever, the content of iron was $31.93 \mu \mathrm{g} / \mathrm{g}$ in the femur, $27.04 \mu \mathrm{g} / \mathrm{g}$ in the tibia, and $38.68 \mu \mathrm{g} / \mathrm{g}$ in the meniscus.

Iron content in bone tissues can also vary geographically, which has been confirmed by the results reported by Yoshinaga et al. on iron content in rib bones $(71.0 \mu \mathrm{g} / \mathrm{g}) .{ }^{30}$ Like in our study, they found no statistically significant differences between women and men.

Assessment of the content of elements in the bones obtained from archeological excavations is commonly reported. Vuorinen et al. determined that Fe content in the ribs of skeletons found in excavations was $5691 \mu \mathrm{g} / \mathrm{g}$ on average. ${ }^{31}$ The iron level was lower in the group of women $(5564 \mu \mathrm{g} / \mathrm{g})$ as compared to men $(6914 \mu \mathrm{g} / \mathrm{g})$.

Research into the content of iron conducted by Helliwell et al. in the femoral bone in people with fractures and degenerative lesions is methodologically comparable with the current results. ${ }^{32}$ A considerably higher content of iron was noted in patients with fractures $(275.2 \mu \mathrm{g} / \mathrm{g})$ as compared to degenerations $(115 \mu \mathrm{g} / \mathrm{g})$.

The data reported by Kosuga et al. refers to the content of elements in the bones (ribs) from Japan dated back to 120-5000 years B.C. ${ }^{33}$ The level of Fe was found to undergo changes from $104 \mu \mathrm{g} / \mathrm{g}$ to $10970 \mu \mathrm{g} / \mathrm{g}$, being the lowest in the Kofun epoch and the highest in the Edo epoch.

In a study performed by Hisanaga et al., Fe content in excavated bones ranged from $35.5 \mu \mathrm{g} / \mathrm{g}$ to $2793.8 \mu \mathrm{g} / \mathrm{g}$, being the highest in the Edo epoch. ${ }^{34}$

In this part of the discussion, it should be emphasized that the iron content in bones from excavations is many times higher as compared to the levels observed in our study. The content of iron was also affected by diagenesis processes taking place in the soil, as well as the use of iron-made vessels and goods.

\section{Conclusions}

In patients who underwent endoprosthesoplasty of the knee joint, statistically significant differences were found in the levels of iron in various components of the knee joint.

The differences in iron content in the knee joint between women and men were not statistically significant. Thehighest iron content was found in the femur of the knee joint, then in the meniscus, and the lowest in the tibia. However, the differences were not statistically significant. 
Smokers had lower Fe content in the knee joint tissues than nonsmokers.

A correlation was found between iron content in the knee joint and $\mathrm{RBC}$ in women (rho $=-0.19$ ) and men $(\mathrm{rho}=-0.34)$, and HCT in women $(\mathrm{rho}=-0.19)$ and men $($ rho $=-0.31)$.

\section{References}

1. Nordberg GF, Fowler BA, Nordberg M, Friberg L. Handbook on the Toxicology of Metals. $3^{\text {rd }}$ edition. Burlington, MA, San Diego, CA, London: Elsevier; 2007:577-594.

2. Zofková I, Nemcikova P, Matucha P. Trace elements and bone health. Clin Chem Lab Med. 2013;51:1555-1561.

3. Medeiros DM, Stoecker B, Plattner A, Jennings D, Haub M. Iron deficiency negatively affects vertebrae and femurs of rats independently of energy intake and body weight. J Nutr. 2004;134:3061-3067.

4. Parelman M, Stoecker B, Baker A, Medeiros D. Iron restriction negatively affects bone in female rats and mineralization of $\mathrm{hFOB}$ osteoblast cells. Exp Biol Med. 2006;231:378-386.

5. Park J, Kamendulis LM, Klaunig JE. Mechanisms of 2-butoxyethanol carcinogenicity: Studies on Syrian Hamster Embryo (SHE) cell transformation. Toxicol Sci. 2002;68:43-50.

6. Medeiros DM, Plattner A, Jennings D, Stoecker B. Bone morphology, strength and density are compromised in iron-deficient rats and exacerbated by calcium-restriction. J Nutr. 2002;132:3135-3141.

7. Medeiros DM, llich J, Ireton J, Matkovic V, Shiry L, Wildman R. Femurs from rats fed diets deficient in copper or iron have decreased mechanical strength and altered mineral composition. J Trace Elem Exp Med. 1997;10:197-203.

8. Zhang JK, Liu Y, Meng GL, et al. Protection by salidroside against bone loss via inhibition of oxidative stress and bone-resorbing mediators. PLoS One. 2013;8(2): e57251. doi: 10.1371/journal. pone.0057251.

9. Diaz-Castro J, Lopez-Frias MR, Campos MS, et al. Severe nutritional iron-deficiency anemia has a negative effect on some bone turnover biomarkers in rats. Eur J Nutr. 2012;51:241-247.

10. Diaz-Castro J, Lopez-Frias MR, Campos MS, et al. Goat milk during iron repletion improves bone turnover impaired by severe iron deficiency. J Dairy Sci. 2011;94: 2752-2761.

11. Guggenbuhl P, Deugnier Y, Boisdet JF, et al. Bone mineral density in men with genetic hemochromatosis and HFGE gene mutation. Osteoporosis Int. 2005;16:1809-1814.

12. Katsumata S, Katsumata-Tsuboi R, Uehara M, Suzuki K. Severe iron deficiency decreases both bone formation and bone resorption in rats. J Nutr. 2009;139:238-243.

13. Harris MM, Houtkooper LB, Stanford VA, et al. Dietary iron is associated with bone mineral density in healthy postmenopausal women. J Nutr. 2003;133:3598-3602.

14. Jian J, Pelle E, Huang X. Iron and menopause: Does increased iron affect the health of postmenopausal women? Antioxid Redox Signal. 2009;11:2939-2943.

15. D'Amelio P, Cristofaro MA, Tamone C, et al. Role of iron metabolism and oxidative damage in postmenopausal bone loss. Bone. 2008:43:1010-1015.

16. Sierakowska M, Sierakowski S, Wróblewska M, Krajewska-Kułak E. Problemy zdrowotne pacjentów z chorobą zwyrodnieniową stawów i ich wpływ na jakość życia uwarunkowaną stanem zdrowia. Reumatologia. 2010;48:372-379.

17. Brodziak-Dopierała B, Kwapuliński J, Paukszto A, Kowol J, Bogunia $M$, Ahnert B. Interactions of copper and iron with other elements in the osseous tissue of the femur head. Fresenius Environ Bull. 2009;18:1963-1966.

18. Brodziak B, Kwapuliński J, Bogunia M, et al. The occurrence of $\mathrm{Co}$ Ag, Al, Sr in femur head. Pol J Environ Stud. 2006;15:20-22.

19. Todd AC, Carroll S, Godbold JH, Moshier EL, Khan FA. The effect of measurement location on tibia lead XRF measurement results and uncertainty. Phys Med Biol. 2001;46:29-40.

20. Berglund M, Akesson A, Bjellerup P, Vahter M. Metal-bone interactions. Toxicol Lett. 2000;112-113:219-225.
21. Tzaphlidou M, Zaichick V. Calcium, phosphorus, calcium-phosphorus ratio in rib bone of healthy humans. Biol Trace Elem Res. 2003:93:63-74.

22. Mari M, Nadal M, Schuhmacher M, Barbería E, García F, Domingo JL. Human exposure to metals: Levels in autopsy tissues of individuals living near a hazardous waste incinerator. Biol Trace Elem Res. 2014;159:15-21.

23. Beneš B, Jakubec K, Šmíd J, Spěváčková V. Determination of thirty-two elements in human autopsy tissue. Biol Trace Elem Res. 2000;75:195-203

24. Kuo HW, Kuo SM, Chou CH, Lee TC. Determination of 14 elements in Taiwanese bones. Sci Total Environ. 2000;255:45-55.

25. Bush VJ, Moyer TP, Batts KP, Parisi JE. Essential and toxic element concentrations in fresh and formalin-fixed human autopsy tissues. Clin Chem. 1995;41:284-294.

26. Zaichick V, Zaichick S, Karandashev V, Nosenko S. The effect of age and gender on $\mathrm{Al}, \mathrm{B}, \mathrm{Ba}, \mathrm{Ca}, \mathrm{Cu}, \mathrm{Fe}, \mathrm{K}, \mathrm{Li}, \mathrm{Mg}, \mathrm{Mn}, \mathrm{Na}, \mathrm{P}, \mathrm{S}, \mathrm{Sr}, \mathrm{V}$, and $\mathrm{Zn}$ contents in rib bone of healthy humans. Biol Trace Elem Res. 2009;129:107-115.

27. Scancar J, Milacic R, Bendikt M, Bukovec P. Determination of trace elements and calcium in bone of the human iliac crest by atomic absorption spectrometry. Clin Chim Acta. 2000;293:187-197.

28. Takata MK, Saiki M, Sumita NM, Saldiva PHN, Pasqualucci CA. Trace element determinations in human cortical and trabecular bones. J Radioanal Nucl Chem. 2005;264:5-8.

29. Yoshinaga J, Suzuki T, Morita M, Hayakawa M. Trace elements in ribs of elderly people and elemental variation in the presence of chronic diseases. Sci Total Environ. 1995;162:239-252.

30. Brodziak-Dopierała B, Kwapuliński J, Sobczyk K, Wiechuła D. The content of manganese and iron in hip joint tissue. J Trace Elem Med Biol. 2013;27;208-212.

31. Vuorinen HS, Pihlman S, Rauhamaa-Mussalo H, Tapper U, Varrela T. Trace and heavy metal analyses of a skeletal population representing the town people in Turku (Abo), Finland in the $16^{\text {th }}-17^{\text {th }}$ centuries: With special reference to gender age and social background. Sci Total Environ. 1996;177:145-160.

32. Helliwell TR, Kelll SA, Walsh HPJ, et al. Elemental analysis of femoral bone from patients with fractured neck of femur or osteoarthrosis. Bone. 1996;18:151-157.

33. Kosugi $H$, Hanihara $K$, Suzuki $T$, et al. Elemental composition of ancient Japanese bones. Sci Total Environ. 1986;52:93-107.

34. Hisanaga A, Hirata M, Tanaka A, Ishinishi N, Eguchi Y. Variation of trace metals in ancient and contemporary Japanese bones. Biol Trace Elem Res. 1988;22:221-231. 